doi: $10.15407 /$ ukrbotj73.03.234

\author{
S. SAEIDI MEHRVARZ, E. MOHARAMI \\ Department of Biology, Faculty of Sciences, University of Guilan \\ PO Box 41335-1914, Rasht, Iran \\ saeidimz@guilan.ac.ir
}

\title{
ANATOMICAL STUDY ON SOME SPECIES OF GENUS CYPERUS IN NORTHERN IRAN
}

Saeidi Mehrvarz S., Moharami E. Anatomical study on some species of genus Cyperus in northern Iran. Ukr. Bot. J., 2016, 73(3): 234-238.

\begin{abstract}
Comparative anatomy of six taxa of Cyperus distributed in the north of Iran was studied. The investigated species are: $C$. difformis, $C$. distachyos, $C$. fuscus, $C$. pygmaeus, $C$. odoratus subsp. transcaucasicus, and $C$. rotundus. Cross sections of stems and leaves of these species were examined. The following characters were determined to be taxonomically informative: cross-section shape of the aerial stem, presence or absence of vascular bundle in the central part of stem cross-sections, the diameter of mesophyll and air cavities in stem and leaf cross-sections. Cyperus fuscus and C. difformis differ from other studied species in having large air cavities in stem and leaf cross section. Our results show that comparative anatomy of lateral stems and leaves may provide additional characters to be considered in taxonomic studies within this genus.
\end{abstract}

Key words: anatomy, taxonomy, Cyperus, Iran

\section{Introduction}

The genus Cyperus L. comprises about 950 species distributed throughout tropical and temperate regions of the world (Larridon et al., 2013). This genus is represented by 31 species in Iran of which 17 occur in northern Iran. The genus Cyperus is the second largest genus of the family Cyperaceae in the flora of Iran. These taxa are annual or perennial herbs, with rhizomes or stolons; culms caespitose or solitary, erect, usually 3-angled or acutely triquetrous; leaves basal, 3-ranked, spikelets few to many in spikes; stigmas (2 or) 3, deciduous at maturity, nutlet 3-sided. Cyperus difformis L., C. fuscus L. and C. distachyos All. are distributed in Europe, Africa, Asia, and Australia, and are naturalized in other areas of the world. Cyperus pygmaeus Rottb. was collected by Haussknekht from southern Iran (Boissier, 1884) and has been recently reported from northwestern Iran by Naqinezhad \& Ghahreman (2004); however, there is no certain report on the species of this subgenus in Flora Iranica (Kukkonen, 1998). This species is also distributed in India, Caucasus and eastern Turkey. Cyperus odoratus L. subsp. transcaucasicus (Palla) Kukkonen is an emergenthygrophytic plant and belongs to Euro-Siberian element (Saeidi Mehrvarz, Ashouri Nodehi, 2015). Cyperus rotundus $\mathrm{L}$. is a cosmopolitan element and can be found in a wide variety of habitats including cultivated fields, waste areas, roadsides, pastures, riverbanks, sandbanks, irrigation channels, river and stream shores and natural areas. The anatomy of some Cyperus species along with other genera of Cyperaceae has previously been studied (c) S. SAEIDI MEHRVARZ, E. MOHARAMI, 2016 by Metcalfe (1971). A few additional studies have been published on leaf and stem anatomy in Cyperus. Amini Rad \& Sonboli (2008) studied 10 Iranian species of Cyperus using light microscopy. Anatomical features of some species of Cyperaceae from northeastern Brazil have also been carried out (Martins, Alves, 2009; Martins, Scatena, 2013). The aim of the present study was to examine anatomical evidence in the species of Cyperus distributed in northern Iran, in order to provide additional information for the taxonomic delimitation at genus level. In this study, leaf and stem anatomy of six species of the genus Cyperus, with the exception of C. rotundus, are provided for the first time.

\section{Materials and methods}

Fresh and dried samples from IRANand $G U H$ (University of Guilan) Herbaria were used for this study. The list of examined specimens is given in Table 1. Dry materials were fixed in the proportion 1:1 of ethanol and glycerin. Cross sections were made with a razor; they were cleared with sodium hypoclorite and stained with Methyl green and Congo red (Vardar, 1987). Then transverse sections were mounted on microscopic slides and observed with Letiz light microscope model, photographed by Nikon microscope and Hitels camera (Model: G22A) .

\section{Results}

The most important anatomical characters of the investigated species of Cyperus are given in Table 2. A detailed study of anatomical features of six species of Cyperus is provided as follows: 
Table 1. Taxonomic assignment and voucher information for the examined Cyperus species

\begin{tabular}{|c|c|}
\hline Localities & Taxa \\
\hline $\begin{array}{l}\text { Guilan: } 14 \mathrm{~km} \text { from Astara to Talesh, Ghare-su, } 40 \text { M, Amini Rad and Tehrani, } \\
2007 \text { (IRAN 34448) } \\
\text { Guilan: Rudsar, seaside, Amini Rad, } 2006 \text { (IRAN 43607) } \\
\text { Mazandaran: Fereydoon Kenar, Saeidi Mehrvarz (GUH 5243) }\end{array}$ & C. difformis \\
\hline $\begin{array}{l}\text { Guilan: Rudbar to Ghazvin, Lowshan, Amini Rad, } 2002 \text { (IRAN 34451) } \\
\text { Guilan: Boujagh, Saeidi Mehrvarz (GUH 5248) } \\
\text { Guilan: Astara, Estil wetland, Khodadadi (GUH 5249) } \\
\text { Guilan: Rezvanshahr, Vahdati (GUH 5250) }\end{array}$ & C. distachyos \\
\hline $\begin{array}{l}\text { Mazandaran: } 10 \mathrm{~km} \text { from Amol to Babol, Amini Rrad, } 2007 \text { (IRAN 48933) } \\
\text { Guilan: Talesh, } 7 \mathrm{~km} \text {, Amini Rad (IRAN 34985) }\end{array}$ & C. fuscus \\
\hline $\begin{array}{l}\text { Guilan: Kiashahr, Maghsoodi, } 2013 \text { (GUH 5241) } \\
\text { Guilan: Astara, Bazdid Vahdati, } 2011 \text { (GUH 5242) } \\
\text { Guilan: Rudsar, Seaside, Amini Rad, } 2006 \text { (IRAN 43623) }\end{array}$ & C. odoratus subsp. transcaucasicus \\
\hline Guilan: Astara, Estil wetland, Moharrami 2014 (GUH 5247) & C.pygmaeus \\
\hline $\begin{array}{l}\text { Guilan: Rasht, Musavi (GUH 5244) } \\
\text { Guilan: Rudsar, Seaside, Moharrami, } 2014 \text { (GUH 5245) } \\
\text { Guilan: Astara, Estil Wetland, Khodadadi (GUH 5246) }\end{array}$ & C. rotundus \\
\hline
\end{tabular}

Table 2. Anatomical features of the investigated species of Cyperus

\begin{tabular}{|c|c|c|c|c|c|c|}
\hline Character & C. difformis & C. distachyos & C. fuscus & C. odoratus & C.pygmaeus & C. rotundus \\
\hline $\begin{array}{l}\text { Sclerenchyma } \\
\text { strands in upper } \\
\text { midrib (abaxial) }\end{array}$ & 2 & 2 & 2 & $3-4$ & 2 & 2 \\
\hline $\begin{array}{l}\text { Number of } \\
\text { bulliform cells in } \\
\text { leaf }\end{array}$ & $4-6$ & $5-6$ & $5-6$ & $6-8$ & $4-6$ & $6-10$ \\
\hline $\begin{array}{l}\text { Number of air } \\
\text { cavities in leaf }\end{array}$ & $14-16$ & $18-21$ & $14-25$ & $25-28$ & $17-20$ & $26-30$ \\
\hline $\begin{array}{l}\text { Number of } \\
\text { vascular bundles } \\
\text { in leaf }\end{array}$ & $15-18$ & $27-29$ & $15-26$ & $41-65$ & $25-27$ & $52-74$ \\
\hline $\begin{array}{l}\text { Mesophyll } \\
\text { diameter }\end{array}$ & $\begin{array}{c}140(162.22 \\
\pm 0.68) 182.22\end{array}$ & $\begin{array}{l}34.44(43.11 \\
\pm 0.34) 55.55\end{array}$ & $\begin{array}{l}68.88(75.33 \\
\pm 0.26) 82.22\end{array}$ & $\begin{array}{l}55.55(66.66 \\
\pm 0.5) 77.77\end{array}$ & $\begin{array}{c}46.66(50 \\
\pm 0.10) 53.33\end{array}$ & $\begin{array}{l}66.66(109.55 \\
\pm 1.36) 144.44\end{array}$ \\
\hline $\begin{array}{l}\text { Number of } \\
\text { vascular bundles } \\
\text { in stem }\end{array}$ & $22-27$ & $23-81$ & $28-37$ & $38-190$ & $74-80$ & $107-124$ \\
\hline $\begin{array}{l}\text { Cross-section of } \\
\text { aerial stem }\end{array}$ & $\begin{array}{l}\text { triangular with } \\
\text { acute corners }\end{array}$ & circular & $\begin{array}{l}\text { triangular with } \\
\text { acute corners }\end{array}$ & $\begin{array}{l}\text { triangular with } \\
\text { rounded corners }\end{array}$ & $\begin{array}{c}\text { triangular } \\
\text { with rounded } \\
\text { corners }\end{array}$ & $\begin{array}{c}\text { triangular } \\
\text { with rounded } \\
\text { corners }\end{array}$ \\
\hline
\end{tabular}

Stem

Specimen examined to $2.7 \mathrm{~mm}$ in diameter. Acutely triangular rarely circular; sides almost flat to slightly concave, with acute or rounded corners, grooved. Sclerenchyma: few or numerous hypodermal strands with various sizes, mostly triangular to semispherical in sides and pulviniform to subrectangular in angles, two large in angles of stem, sometimes one between air cavities. Assimilatory tissue: chlorenchyma with various sizes of rounded cells, radiate or subradiate around small peripheral vascular bundle $(\mathrm{vb})$. Vascular bundles: numerous, various sizes, scattered in ground tissue, more in peripheral ground tissue. Ground tissue: very spongy with numerous small air cavities. Air cavities: numerous and large (Fig. 1).

\section{Leaf}

Specimen examined to $6.5 \mathrm{~mm}$ wide. Shallow flanged to flanged V-shaped, keeled; margins unequal sides, one rounded and the other tapered to narrower point. 


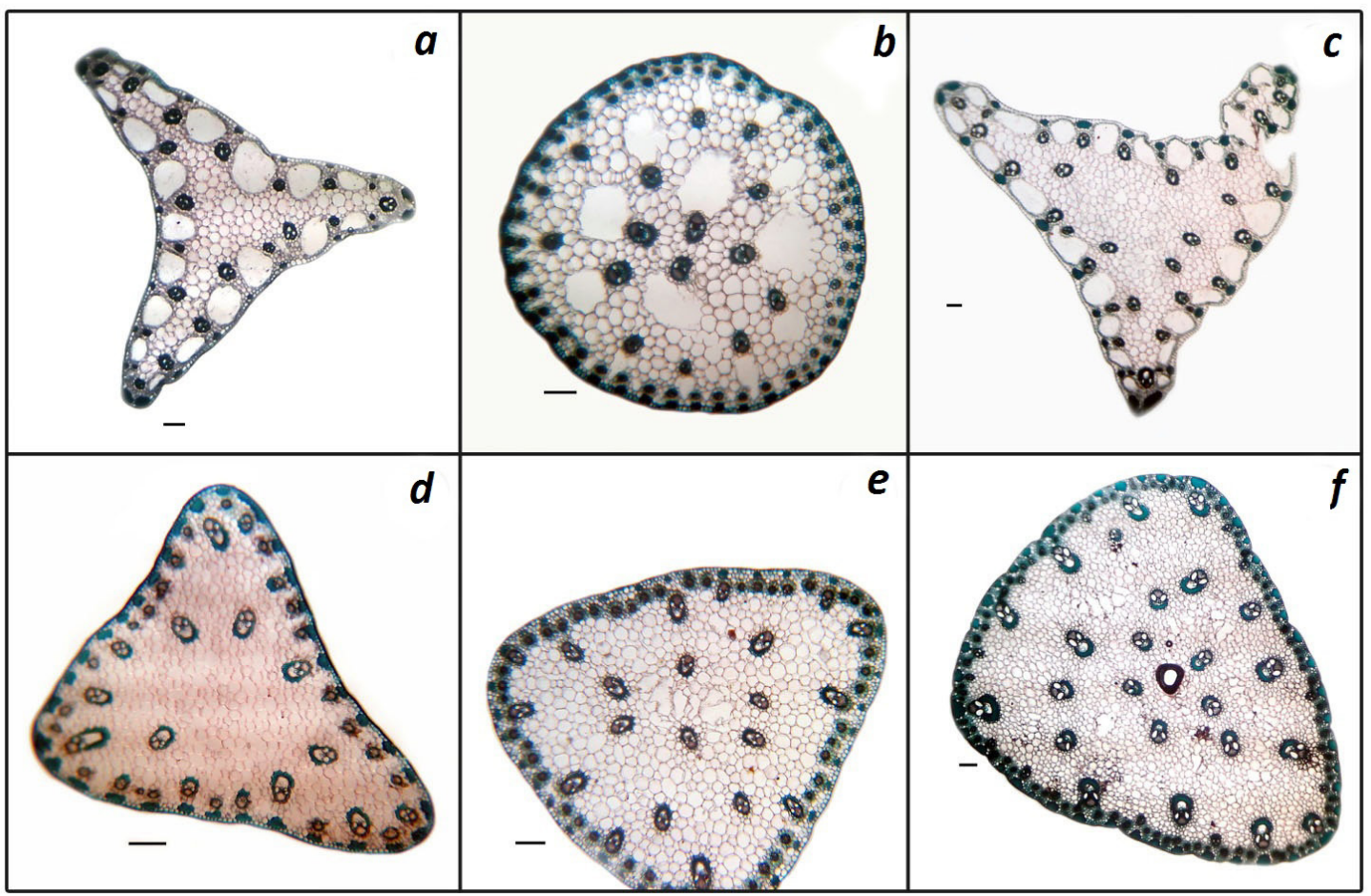

Fig. 1. Stem cross-sections in Cyperus species: $a-C$. difformis, $b-C$. distachyos, $c-C$. fuscus, $d-C$. odoratus subsp. transcaucasicus, $e-C$. pygmaeus, $f-C$. rotundus. Scale bar: $100 \mu \mathrm{m}$.

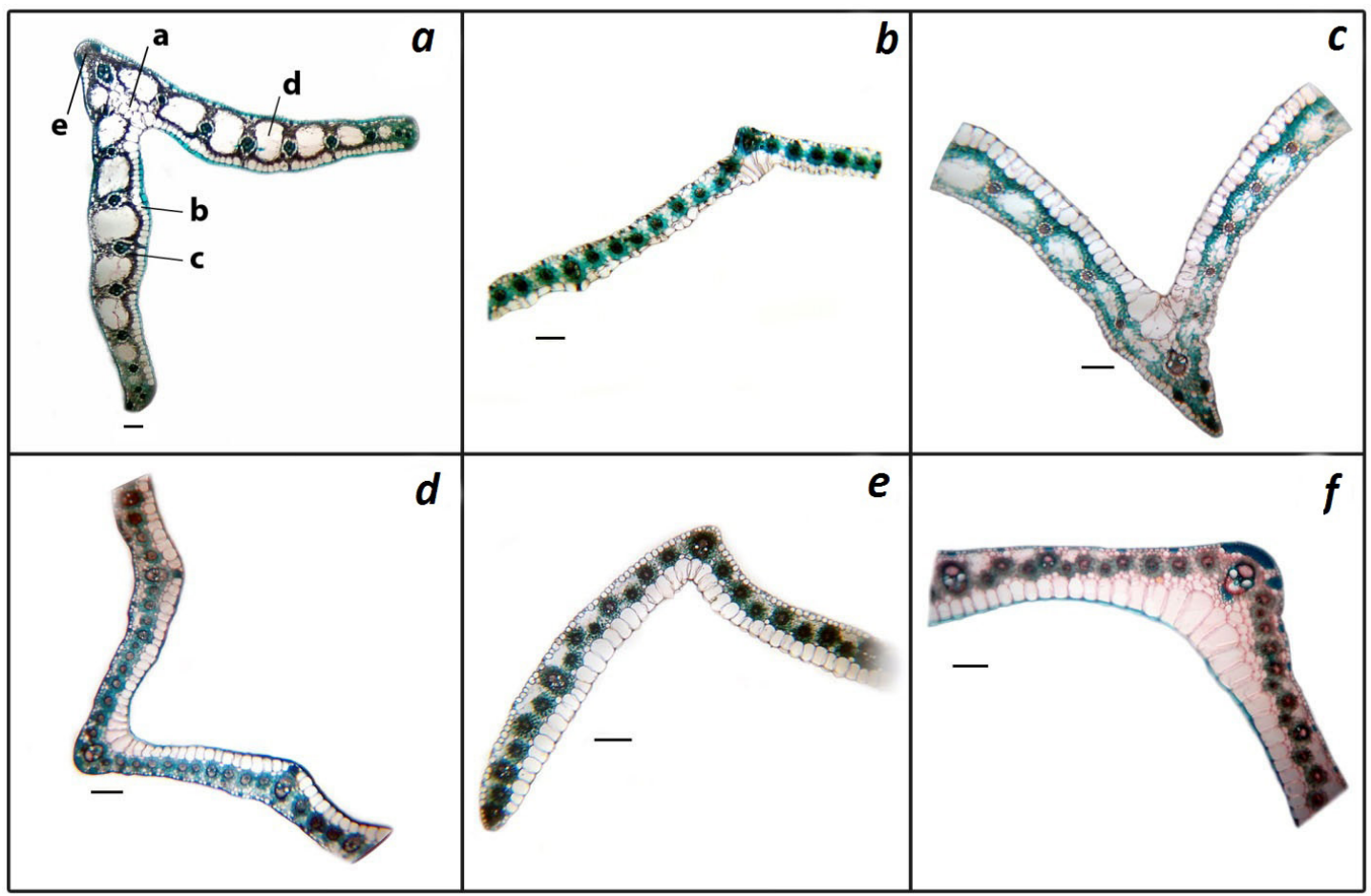

Fig. 2. Leaf cross-sections in Cyperus species: $a-C$. difformis, $b-C$. distachyos, $c-C$. fuscus, $d-C$. odoratus subsp. transcaucasicus, $e-C$. pygmaeus, $f-C$. rotundus. Scale bar: $100 \mu \mathrm{m}$. Abbreviations: a - bulliform cells, b - epiderm, c - vascular bundles, $\mathrm{d}-$ air cavity, e - sclerenchyma strands. 
Hypodermis: adaxial of one to two layers of large and 1-2 layers of small translucent cells, oblong to polygonal cells. Sclerenchyma: median vb accompanied by $2-4$ triangular, abaxial strands and by pulviniform to domeshaped, adaxial cap. Principal vbs in each half of leaf with variously shaped and sized abaxial and adaxial strands; largest adaxial strands triangular. Small vbs on adaxial side of air cavities mostly accompanied by sclerenchyma. Mesophyll: chlorenchyma bounded adaxially by translucent hypodermis; portions of chlorenchyma on abaxial side of vbs connected to abaxial epidermis by none or only one layer of broad to low girders of translucent cells. Air cavities: conspicuously large, except near leaf margins, middle to small size towards leaf margins and midrib. Vascular bundles: various sizes in each half of leaf. Bundle sheaths: obscurely double or double (Fig. 2).

\section{Discussion}

Anatomical studies showed that the stems of all examined species were obtuse or acute triangular in transverse section, except for $C$. distachyos belonging to subgenus Juncellus which was circular. Size of air cavities in stem are large in $C$. distachyos, $C$. difformis, and C. fuscus, respectively. According to Metcalfe (1971), the presence of air cavities is an important character for separating species of this genus. The present results from this study of $C$. rotundus confirm the previous findings (Metcalfe, 1971; Amini Rad, Sonboli, 2008). The presence of vascular bundle in the central part of stem cross-sections of $C$. distachyos, $C$. pygmaeus, and $C$. rotundus is a characteristic feature of the studied taxa. All taxa showed dorsiventral leaves. In our study, adaxial hypodermis is composed of 2 layers of large parenchymatous cells in $C$. difformis, C. fuscus, and $C$. rotundus, while in other species it consists of one layer. Both abaxial and adaxial epidermis were uniseriate and adaxial epidermis was larger than the abaxial one in all species because of the presence of bulliform cells. These cells were present directly above median vascular bundle; however, the presence of bulliform cells in $C$. difformis is a great taxonomic value for this genus (Fig. 1a). According to Metcalfe (1971), expansion or contraction of these cells is responsible for the rolling and unrolling or for folding and unfolding of leaves. In species of Bolboschoenus, as well as in other Cyperaceae, bulliform cells also occur in the leaf (Amini Rad, Hroudová, 2013). Generally the mesophyll consists of irregularly shaped parnchyma cells. The smallest mesophyll diameter belonged to C. distachyos [34.44(43.11 \pm 0.34$) 55.55]$ and the largest one to $C$. difformis [140(162.22 \pm 0.68$) 182.22]$. Leaves in outline were usually keeled, while in $C$. distachyos, $C$. pygmaeus, and $C$. rotundus they were shallow flanged V-shaped. Transverse section of $C$. odoratus subsp. transcaucasicus has an abaxial keel and more than three to four sclerenchymatus strands above median $\mathrm{vb}$, but there are only two strands in other species. The paracytic type stomata are present on the abaxial epidermis. All examined species contained small air cavities in leaf, whilst in $C$. difformis and $C$. fuscus of subgenus Pycnostachys they are large and spheroidal to elliptical. These two species are primarily wetland plants, they frequently grow in habitats with fluctuating water levels, temporarily dry or flooded, which requires adaptations to both drought and flooding (Leite et al., 2009). According to Amini Rad and Sonboli (2008), in xerophyte $C$. bulbosus the number of air cavities were scarce.

In conclusion, anatomical studies revealed that C. distachyos, C. difformis, and C. fuscus have two kinds of air cavities in the stem and this character can differentiate them from other taxa.

\section{Acknowledgements}

The authors are grateful to Mr. Avid Azadnia (M.Sc. of Botany Student in Tehran University) for preparing figures. 


\section{REFERENCES}

Amini Rad M., Sonboli A. Leaf and stem anatomy of the Cyperus subgenus Cyperus in Iran, Rostaniha, 2008, 9: $1-17$.

Amini Rad M., Hroudová Z. Leaf and stem anatomy in Iranian Bolboschoenus species (Cyperaceae), as related to their taxonomy and ecology, Iran. J. Bot., 2013, 19(2): 221-234.

Boissier E. Flora Orientalis, Genevae et Basileae, 1884, 5, pp. 363-378.

Kukkonen I. Cyperaceae. In: Flora Iranica, Ed. Rechinger K.H., Graz: Akademische Druck-u. Verlagsanstalt, 1998, 173, pp. 1-307.

Larridon I., Bauters K., Reynders M., Huygh W., Muasya M., Simpson D.A., Goetghebeur P. Towards a new classification of the giant paraphyletic genus Cyperus (Cyperaceae): phylogenetic relationships and generic delimitation in $\mathrm{C}_{4}$ Cyperus, Bot. J. Linnean Soc., 2013, 172(1): 106-126.

Leite K.R.B., Franca F., Scatena V.L. Anatomy of amphibious Cyperaceae species from lakes in semi-arid region of Bahia State, Brazil, Acta Bot. Brasil., 2009, 23(3): 786-796.

Martins S., Scatena V.L. Developmental anatomy of Cyperus laxus (non-Nranz) and Fimbristylis dichotoma (Kranz) (Cyperaceae, Poales) and tissue continuity, Ann. Acad. Bras. Ciênc., 2013, 85(2): 605-613.

Martins S., Alves M. Anatomical features of species of Cyperaceae from northeastern Brazil, Brittonia, 2009, 61: $89-200$.

Metcalfe C. R. Anatomyof the monocotyledons. V. Cyperaceae, Oxford: Clarendon Press, 1971, 597 pp.

Naqinezhad A. R., Ghahreman A. New noteworthy records for the Cyperaceae flora of Iran, Iran. J. Bot., 2004, 10(2): $185-187$.

Saeidi Mehrvarz S., Ashouri Nodehi M. A floristic study of the Sorkhankol Wildlife Refuge, Guilan province, Iran, Caspian J. Env. Sci., 2015, 13: 183-196.

Vardar Y. Botanikte Preparasyon Tekniği, İzmir: Ege Üniversitesi Fen Fakültesi Basımevi, 1987, no. 2.

Recommended for publication by

Submitted 16.03.2016

V.P. Hayova
Саеді Мехрварз С., Мохарамі Е. Дослідження анатомії деяких видів роду Cуреrus із північного Ірану. - Укр.

ботан. журн. - 2016. - 73(3): 234-238.

Університет Гілян

41335-1914, Рашт, Іран

Проведене порівняльне вивчення анатомії шести таксонів роду Cyperus, поширених на півночі Ірану: C. difformis, C. distachyos, C. fuscus, C. pygmaeus, C. odoratus subsp. transcaucasicus i $C$. rotundus. Досліджували поперечні зрізи стебел і листків цих видів. Таксономічно важливими визначені такі ознаки: форма поперечного зрізу повітряного стебла, наявність або відсутність судинного пучка в центральній частині поперечних зрізів стебла, діаметр мезофіла і повітряних порожнин в поперечних зрізах стебел і листя. Cyperus fuscus i $C$. difformis відрізняються від інших вивчених видів наявністю великих повітряних порожнин в поперечних зрізах стебел і листків. Наші результати показують, що порівняльна анатомія бічних стебел і листків може забезпечити додаткові ознаки для таксономічних досліджень цього роду.

Ключові слова: анатомія, таксономія, Cyperus, Iран

Саеди Мехрварз С., Мохарами Е. Исследование анатомии некоторых видов рода Cyperus из северного Ирана. - Укр. ботан. журн. - 2016. - 73(3): 234-238.

Университет Гилян

41335-1914, Рашт, Иран

Проведено сравнительное изучение анатомии шести таксонов рода Cyperus, распространенных на севере Ирана: $C$. difformis, C. distachyos, $C$. fuscus, $C$. pygmaeus, $C$. odoratus subsp. transcaucasicus и $C$. rotundus. Исследовали поперечные срезы стеблей и листьев этих видов. Таксономически важными определены следующие признаки: форма поперечного среза воздушного стебля, наличие или отсутствие сосудистого пучка в центральной части поперечных срезов стебля, диаметр мезофилла и воздушных полостей в поперечных срезах стеблей и листьев. Cyperus fuscus и $C$. difformis отличаются от других изученных видов наличием больших воздушных полостей в поперечных срезах стеблей и листьев. Наши результаты показывают, что сравнительная анатомия боковых стеблей и листьев может обеспечить дополнительные признаки для таксономических исследований этого рода.

Ключевые слова: анатомия, таксономия, Cyperus, Иран 